\title{
Provision of aquatic ecosystem services as a consequence of societal changes: The case of the Baltic Sea
}

\section{Hyytiäinen, Kari}

2021-01

Hyytiäinen , K, Barbara , B , Bly Joyce , K, Ehrnsten, E, Eilola , K, Gustafsson , B , Meier , M , Norkko , A , Saraiva , S , Tomczak , M \& Zandersen , M 2021, ' Provision of aquatic ecosystem services as a consequence of societal changes: The case of the Baltic Sea ' , pÿPopulation Ecology , vol. 63 , no. 1 , pp. 6174 . https://doi.org/10.1002/1438-390X.12033

http://hdl.handle.net/10138/326236

https://doi.org/10.1002/1438-390X.12033

acceptedVersion

Downloaded from Helda, University of Helsinki institutional repository.

This is an electronic reprint of the original article.

This reprint may differ from the original in pagination and typographic detail.

Please cite the original version. 


\section{Provision of aquatic ecosystem services as a consequence of societal changes: the case of the Baltic Sea}

Kari Hyytiäinen ${ }^{1 *}$, Barbara Bauer ${ }^{2}$, Kerstin Bly Joyce ${ }^{2}$, Eva Ehrnsten ${ }^{2,5}$, Kari Eilola ${ }^{3}$, Bo G. Gustafsson ${ }^{2,5}$, H.E. Markus Meier ${ }^{4,3}$, Alf Norkko ${ }^{5,2}$, Sofia Saraiva ${ }^{6}$, Maciej Tomczak², Marianne Zandersen ${ }^{7}$

${ }^{1}$ Department of Economics and Management, University of Helsinki, Finland

${ }^{2}$ Stockholm University Baltic Sea Centre, Stockholm, Sweden

${ }^{3}$ Swedish Meteorological and Hydrological Institute, Norrköping, Sweden

${ }^{4}$ Leibniz Institute for Baltic Sea Research Warnemünde, Rostock, Germany

${ }^{5}$ Tvärminne Zoological Station, University of Helsinki, Hanko, Finland

${ }^{6}$ University of Lisbon, Instituto Superior Técnico, Environment and Energy Section, Lisbon, Portugal

7 Department of Environmental Science, iClimate Interdiciplinary Centre for Climate Change, Aarhus University, Roskilde, Denmark

* corresponding author, kari.hyytiainen@helsinki.fi, +358-50-4160702

\section{ABSTRACT}

Aquatic ecosystem services are important for human wellbeing, but they are much less studied than terrestrial ecosystem services. The objectives of this study are to broaden, itemize and exemplify the human-nature interactions in modelling the future provision of aquatic ecosystem services. We include shared socioeconomic and representative concentration pathways, used extensively in climate research, as drivers of change for the future development of the Baltic Sea. Then we use biogeochemical and ecosystem models to 
demonstrate the future development of exemplary supporting, provisioning, and cultural ecosystem services for two distinct combinations of regionally downscaled global climate and socioeconomic futures. According to the model simulations, the two global futures ('Sustainable well-being' vs. 'Fossil-fuelled development') studied lead to clearly deviating trajectories in the provision of marine ecosystem services. Under the 'Sustainable well-being'scenario primary production decreases by $20 \%$, catches of demersal fish increases and the recreation opportunities increase significantly by the end of the ongoing century. Under the 'fossil-fuelled development'-scenario primary production doubles, fisheries focus on less valued pelagic fish and the recreation possibilities will decrease. Long-term projections of aquatic ecosystem services prepared for alternative global socioeconomic futures can be used by policy makers and managers to adaptively and iteratively adjust mitigation and adaptation effort with plausible future changes in the drivers of water pollution.

Keywords: Baltic Sea, climate change, cyanobacteria bloom, ecosystem services, integrated models, primary production

\section{INTRODUCTION}

Aquatic ecosystems provide a multitude of products and services for human consumption and enjoyment in the form of ecosystem services. However, extractive and polluting uses of the aquatic environments have the potential to seriously reduce and jeopardize the future provision of aquatic ecosystem services important for wellbeing and welfare. This creates urgency to develop approaches and methods that integrate the concept of ecosystem services in the design of mitigation policies and protection efforts.

Ecosystem services became a widely established concept to describe the dependence of human well-being on the properties and functioning of the natural ecosystems following the Millennium Ecosystem Assessment (2005). The concept of ecosystem services helped us to structure and better understand the rich variety of direct and indirect interactions between 
human and natural systems. Also, it has created a common language to bridge natural and social sciences.

Much of the literature on ecosystem services has focused on creating typologies and classifications (Fisher et al. 2009; Haines-Young and Potschin 2012; La Notte et al. 2017). Although focus has been on terrestrial ecosystems, Atkins et al. (2011), Hattam et al. (2015) and Liquete et al. (2013) have developed generic classifications also for marine ecosystem services. The adoption of ecosystem services as a central concept in policy processes, e.g. the EU Marine Strategy Framework Directive, has increased motivation for valuing the changes in the provision of ecosystem services (e.g. Mace and Bateman 2011). Börger et al. (2014) compared the approaches and lessons learned from ecosystem service valuation for the purposes of marine planning in the UK and the US, and identified development goals for the wider adoption of non-market valuation techniques as policy guidance. Cole and Moksnes (2016) developed a process for aggregating values of multiple marine ecosystem services based on the changes in ecosystem processes.

Despite substantial research effort, the concept of ecosystems services has not yet been fully operationalized as part of cost-benefit analyses or decision support in political decision making to guide investments in mitigation or protection efforts. Long-term future projections of ecosystem service provision would be useful in ex-ante evaluation of potential consequences of environmental policies, such as protection of our marine environments. Generating such projections is challenging, as it requires a solid understanding of the chain of interactions that lead to changes in ecosystem functions as a response to changes in societal conditions.

Models are essential tools for studying the consequences of disturbances, both anthropogenic and natural, on ecosystem state and provision of ecosystem services (e.g. Ochoa and Urbina-Cardona 2017). There are, however, no systematic approaches for translating changes in the structure and functioning of marine ecosystems as flows of marine ecosystem services. Relevant classification and definitions of ecosystem services are dependent on location as well as the purpose of the analysis (e.g. policy guidance or longterm assessment). Spatially explicit integrated assessment models have been applied to 
predict changes in selected ecosystem services in terrestrial ecosystems (e.g. Bateman et al. 2013; Nelson et al. 2009;). The impacts of global drivers on the occurrence of regime shifts in marine environments were addressed by Rocha et al. (2015). Other studies described the level of attainment of ecosystem services relative to some desired or reference level, but at highly aggregated levels (e.g. Halpern et al. 2012).

Quantitative modelling and application of an integrated modelling of the ecosystem services could be useful for adaptive governance and management of marine areas, as well as for conducting global and regional assessments. However, there are only a few studies that have considered the entire chain of human-nature interactions relevant for the provision of aquatic ecosystems services. Numerical applications of such frameworks are even rarer. Keeler et al. (2012) developed a causal framework that links management actions with water quality and aquatic ecosystem services. They focused on a particular step between the water quality and benefits, but placed smaller emphasis on specification of global and regional drivers. Österblom et al. (2013) put together the main components of the aquatic ecosystem (biogeochemical and physical environment, higher and lower trophic level species) and the human dimensions (economy, knowledge systems, institutions, norms, actors) in a single framework, but did not consider ecosystem services. Hägg et al. (2010) focused on the impacts of changing diets on nutrient pollution in the Baltic Sea, but did not study the consequences for the marine ecosystem. Pouso et al. (2019) developed an integrated socioecological model to study the impacts of various disturbances and policies on the future prospects of recreation fisheries in the Nerbioi estuary in Northern Spain.

In summary, the chain of causal influences (including human impacts on nature and the feedbacks on human wellbeing) have been variably addressed in the earlier literature on quantitative modelling of human-nature interactions. Our objective is to present an example of how linked models can be used to demonstrate the consequences of societal changes on the provision of marine ecosystem services from a regional sea area. We focus, in particular, in demonstrating the potential of biogeochemical and ecosystem modelling in quantification of various important ecosystems services. Ecosystem services are the contribution of natural systems to human wellbeing. In this paper we do not attempt to quantify the monetary value of ecosystem services. Rather we limit the analysis to demonstrate how our combined 
modelling framework could generate projections of a representative sample of aquatic ecosystem services as a result of societal changes. We argue that quantitative projections of different ecosystem services, often measured in varied metrics such as tons or recreation days, may provide the decision makers and analysts with valuable additional information about the richness of various services and the trade-offs and synergies involved in their production.

Our work applies and extends the frameworks developed earlier by Keeler et al. (2012) and Österblom et al. (2013). We include the global drivers as fundamental drivers of change and provide numerical projections for one case study area: the Baltic Sea. First, we present the framework and elaborate the challenges and opportunities of quantification of marine ecosystem services in response to disturbances. Secondly, we itemize the scenarios and modelling tools used for preparing illustrations for the Baltic Sea. We then show the projections of selected ecosystem functions and services as a response of two alternative global futures and discuss the outcomes.

\section{FRAMEWORK FOR PROJECTIONS OF AQUATIC ECOSYSTEM SERVICES}

Specification of causal chains of interaction between the human and natural systems is a requirement for projecting the future flows of ecosystem services. Figure 1 shows the main drivers for provision of aquatic ecosystem services for inland, coastal, and estuarine waters, which are heavily affected by land-borne nutrient loads. Alterations in the socioeconomic and natural drivers are the fundamental causes of change in the provision of ecosystem services from any terrestrial or aquatic ecosystem. Socioeconomic drivers may include population growth, urbanization, economic growth, level of education, technological development and life styles (Zandersen et al., 2019). They define the demand and production of goods and services, drive land use and investments in infrastructure and mitigation efforts both globally and regionally, and eventually determine the levels and types of extractive and polluting uses of an ecological system. Natural drivers include natural variations in geology 
and hydrology, which together with anthropogenic drivers determine the pressures on aquatic ecosystems.

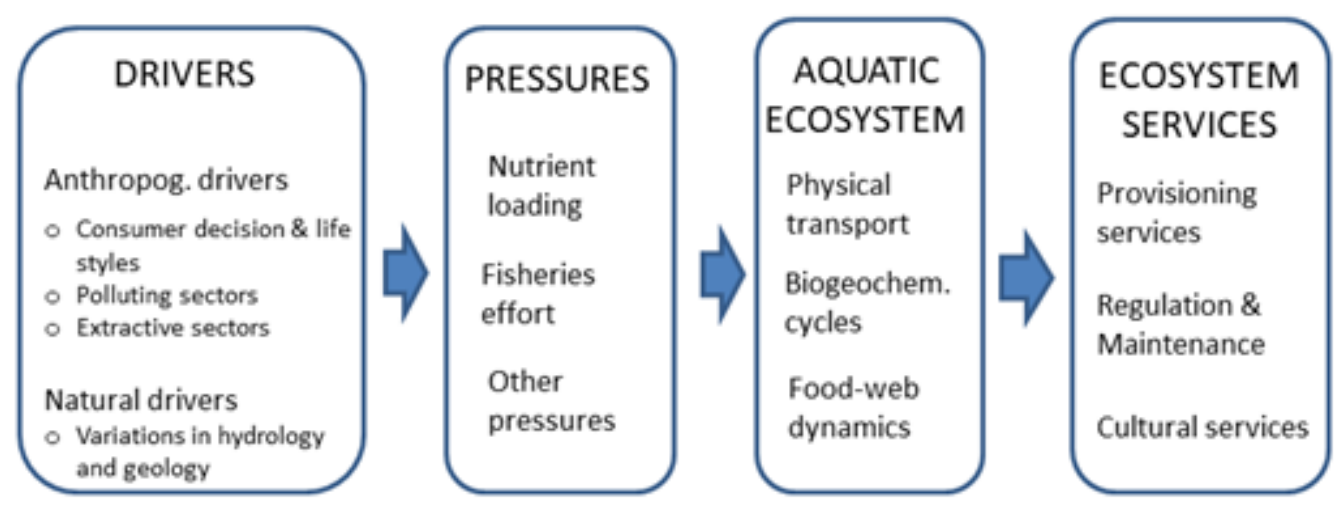

Figure 1. Causal chain of interactions driving the provision of aquatic ecosystem services

We define pressures as 1) flows of energy or matter caused by human activity, and 2) matter extraction such as fishing. In aquatic environments, anthropogenic nutrient loading is an example of pollution that causes eutrophication. Nutrient loading predominantly follows from the externalities of food production and consumption due to inadequate waste treatment. Both extractive and polluting pressures affect the processes of the aquatic system including physical transport, biogeochemical cycles and food web dynamics. Changes in these processes as response to anthropogenic pressures and natural variability of environmental conditions can be estimated using coupled physical, biogeochemical and ecological ecosystem modelling (Meier et al. 2014). The outputs from such models can be translated to a suite of quantitative context-specific descriptors of ecosystem state or indicators that reflect the provision of cultural and provisioning ecosystem services important for human wellbeing. Such descriptors may include temperature, concentration of nutrients, salt and oxygen in the water, abundance and age structure of fish species, and lower trophic levels.

Developing a chain of interactions can be achieved by the analysis of integrated assessment models that include all the causal human-nature relationships in a single mathematical model or by linking existing modelling frameworks describing different elements of the overall system. The DICE-model by Nordhaus (1992) is an example of a holistic, but highly aggregated, 
model that couples the economics, carbon cycle, and climate system for cost-benefit analysis of slowing down global warming. However, the analysis of many regional environmental problems require higher spatial resolution and sectoral analysis. In such cases, an approach linking a cascade of models or model components may turn more informative. Table 1 elaborates on tools needed, requirements for outputs and possibilities and challenges to provide projections of ecosystem services. 
Table 1. Tools needed for quantifying long-term projections of aquatic ecosystem services

\begin{tabular}{|c|c|c|c|c|c|}
\hline Determinants & Tools & Description & Requirements & Possibilities & Challenges \\
\hline \multirow[t]{2}{*}{$\begin{array}{l}\text { Global and } \\
\text { regional } \\
\text { drivers }\end{array}$} & $\begin{array}{l}\text { Socioeco } \\
\text { nomic } \\
\text { scenarios }\end{array}$ & $\begin{array}{l}\text { Coherent and plausible } \\
\text { narratives of societal } \\
\text { developments under alternative } \\
\text { global futures accompanied } \\
\text { with numerical projections. }\end{array}$ & $\begin{array}{l}\text { Projections on economic } \\
\text { sectors that cause } \\
\text { polluting or extractive } \\
\text { use of aquatic } \\
\text { ecosystems }\end{array}$ & $\begin{array}{l}\text { Explicit linking of societal } \\
\text { trends and ecosystems }\end{array}$ & $\begin{array}{l}\text { - Spatial scales of scenarios may not match } \\
\text { - Global socioeconomic futures may not } \\
\text { adequately reflect the extremes with respect } \\
\text { to use of the aquatic ecosystem } \\
\text { - Nonlinearities limit predictive capacity }\end{array}$ \\
\hline & $\begin{array}{l}\text { Climate } \\
\text { scenarios }\end{array}$ & $\begin{array}{l}\text { Plausible representations of } \\
\text { future climate demonstrated by } \\
\text { projections of greenhouse gas } \\
\text { and aerosol concentrations and } \\
\text { modelled responses of the } \\
\text { climate system. }\end{array}$ & $\begin{array}{l}\text { High-resolution climate } \\
\text { information for climate } \\
\text { adaptation and } \\
\text { mitigation and analysis } \\
\text { of other environmental } \\
\text { problems of aquatic } \\
\text { ecosystems }\end{array}$ & $\begin{array}{l}\text { Linking of physical and } \\
\text { biogeochemical changes }\end{array}$ & $\begin{array}{l}\text { - Large uncertainties on the regional scale due } \\
\text { to biases in regional and global climate } \\
\text { models, uncertainties in emission scenarios } \\
\text { and natural variability }\end{array}$ \\
\hline Pressures & $\begin{array}{l}\text { Models } \\
\text { for } \\
\text { pressures }\end{array}$ & $\begin{array}{l}\text { Formalization of scenario } \\
\text { narratives as pressures on the } \\
\text { aquatic ecosystem. Tools } \\
\text { include simple quantifications } \\
\text { of pressure levels or } \\
\text { management targets (e.g. } \\
\text { fishing yields) as well as } \\
\text { complex dynamic models (e.g. } \\
\text { hydrological models of nutrient } \\
\text { transport in the catchment). }\end{array}$ & $\begin{array}{l}\text { Quantifications of } \\
\text { pressures as input for } \\
\text { biogeochemical and/or } \\
\text { ecological models (e.g. } \\
\text { atmospheric deposition, } \\
\text { riverine loads, point } \\
\text { sources for } \\
\text { eutrophication) }\end{array}$ & $\begin{array}{l}\text { Projections on nutrient } \\
\text { load abatement strategies } \\
\text { in changing climate; } \\
\text { fisheries management and } \\
\text { nature conservation } \\
\text { strategies under various } \\
\text { societal contexts }\end{array}$ & $\begin{array}{l}\text { Nutrient load models: } \\
\text { - Long-term changes in soils are unknown } \\
\text { - Large uncertainties in river flow and loads } \\
\text { due to uncertainties in precipitation and } \\
\text { evaporation from climate models } \\
\text { Fisheries management: } \\
\text { - Lack of knowledge about formally linking } \\
\text { socio-economic factors to fishing and fisheries } \\
\text { management practices } \\
\text { - Lack of certainty in maximum sustainable } \\
\text { yield estimates and risk of over-extraction }\end{array}$ \\
\hline $\begin{array}{l}\text { Aquatic } \\
\text { ecosystem } \\
\text { functions and } \\
\text { services }\end{array}$ & $\begin{array}{l}\text { Biogeo- } \\
\text { chemical } \\
\text { models }\end{array}$ & $\begin{array}{l}\text { Process-based quantification of } \\
\text { biogeochemical cycles and } \\
\text { ecosystem state. May include }\end{array}$ & $\begin{array}{l}\text { Ecosystem state and } \\
\text { functioning for } \\
\text { environmental }\end{array}$ & $\begin{array}{l}\text { Calculation of changes in } \\
\text { biogeochemical cycles, } \\
\text { fluxes, eutrophication, } \\
\text { proxies for ecosystem }\end{array}$ & $\begin{array}{l}\text { - Limited process understanding such as the } \\
\text { bioavailability of external nutrient loads } \\
\text { - Sometimes difficult to link to ecosystem } \\
\text { parameters }\end{array}$ \\
\hline
\end{tabular}




\begin{tabular}{|c|c|c|c|c|}
\hline & $\begin{array}{l}\text { the response of lower trophic } \\
\text { levels to eutrophication. }\end{array}$ & $\begin{array}{l}\text { management and } \\
\text { ecosystem services, } \\
\text { definition of targets in } \\
\text { historical reconstructions }\end{array}$ & health & \\
\hline $\begin{array}{l}\text { Ecological } \\
\text { models }\end{array}$ & $\begin{array}{l}\text { Process-based quantification of } \\
\text { ecological processes, such as } \\
\text { food-web interactions, and } \\
\text { ecosystem state. Often focusing } \\
\text { on higher trophic levels. }\end{array}$ & $\begin{array}{l}\text { Ecosystem state and } \\
\text { functioning for } \\
\text { environmental } \\
\text { management and } \\
\text { ecosystem services, } \\
\text { definition of targets in } \\
\text { historical reconstructions }\end{array}$ & $\begin{array}{l}\text { Calculation of changes in } \\
\text { community structure and } \\
\text { population size of } \\
\text { functionally and/or } \\
\text { economically important } \\
\text { organisms, proxies for } \\
\text { ecosystem health and } \\
\text { biodiversity }\end{array}$ & $\begin{array}{l}\text { - Limited process understanding } \\
\text { - Complexity of ecological interactions } \\
\text { - Proliferation of uncertainties when building } \\
\text { models on models }\end{array}$ \\
\hline
\end{tabular}




\section{APPLICATION FOR THE BALTIC SEA}

Here we demonstrate an application of the framework for the Baltic Sea, a shallow (mean depth $52 \mathrm{~m}$ ), semi-enclosed body of brackish water in Northern Europe. Due to its hydrographical characteristics and large catchment, the Baltic Sea ecosystem is vulnerable to natural and anthropogenic disturbances such as climate change and eutrophication (e.g. Elmgren 1989). Baltic fish stocks have been under heavy fishing pressure, which has lead, together with environmental changes, to the current poor status of Eastern Baltic cod stock (ICES, 2019). On the other hand, due to climate impact and lack of top predator pressure clupeids stocks are currently at a high level (ICES, 2019). The elements needed for projecting the future provision of ecosystem services under alternative global developments include scenarios, models and data regarding current emissions and ecosystems state.

\subsection{Regionally downscaled global scenarios}

We build on the socioeconomic and climate scenarios originally developed for the long-term analysis of mitigation and adaptation to climate change. The Shared Socioeconomic Pathways, SSPs (O'Neill et al. 2014) describe five alternative futures for the overall global societal development. The Representative Concentration Pathways, RCPs, (Moss et al. 2010) describe four alternative developments of greenhouse gas concentrations. Such scenarios may also serve as baselines or business-as-usual scenarios for analysing the efforts needed to solve regional environmental problems.

Here we demonstrate the consequences of two extreme global futures, nutrient emission trajectories and fisheries management types on the future provision of aquatic ecosystem services from the Baltic Sea:

(1) 'Fossil-fuelled development'. In this scenario global development is based on continued utilization of fossil fuels (SSP5), which leads to high end climate outcome (RCP8.5). There is no additional water policy effort to control nutrient loading to the Baltic Sea. Fisheries are driven by profit maximization. 
(2) 'Sustainable well-being'. In this scenario, global development driven by fulfilment of the UN sustainability goals (SSP1). Sustainable societal development is coupled with moderate climate change (RCP4.5) and controlled nutrient loads in line with the full implementation of Baltic Sea Action Plan (HELCOM 2007). Fisheries are regulated with an aim of 'ecosystem integrity', i.e., reaching and maintaining high total biomass, especially for the top-predators and species with large body sizes such as seals.

\section{Global and regional climate projections}

For climate projections, we use results from four alternative General Circulation Models (GCMs) prepared for the period 1976-2098. The results from the GCMs were downscaled for the Baltic Sea region (including the catchment areas) by using the regional climate model RCA4-NEMO applied to Europe and parts of the Northeast Atlantic with an interactively coupled Baltic Sea and North Sea (Dieterich et al. 2013, 2019; Gröger et al. 2015, 2019; Wang et al. 2015). The utilized GCMs were: MPI-ESM-LR, EC-EARTH; HadGEM2-ES; and IPSL-CM5AMR. The regional atmosphere model RCA4 has a 0.22 degree spherical, rotated latitude/longitude grid with 40 vertical levels. For details of the regionalization approach, the reader is referred to Saraiva et al. (2019).

\section{Socioeconomic developments}

We make use of global SSPs (O'Neill et al. 2014), numerical extensions of the SSPs publicly available at the IIASA SSP database (Riahi et al. 2017), regionally translated narratives for sectors that drive nutrient pollution (such as wastewater treatment, agricultural production and atmospheric nitrogen deposition) and fisheries in the Baltic Sea region (Zandersen et al. 2019). Under the 'Fossil-fuelled development'-scenario, population increases in the region and globally and the demand for animal proteins increase. As a consequence, agricultural production expands in the Baltic Sea area, one of the rare areas globally where climate change can benefit agricultural production (Parry et al. 2004). Combustion processes will develop in industries, traffic and heat and energy production reducing the nitrate emissions to the atmosphere. The fisheries sector is driven by profit generation motives. Large-scale industrial vessels focusing on catch fish destined to be processed into fish meal and oil become common. 
Under the 'Sustainable well-being'-scenario, there is a gradual transition to diets containing a smaller proportion of animal proteins. Reduced demand for animal production together with decreasing population after the mid-2050s lead to a situation where part of arable land will be converted to other land uses. Investment improving the existing wastewater treatment technologies and on-the-site treatment in rural areas increase. Increasingly stringent environmental policies speed up the reduction of the nutrient loading cost-effectively across sectors and spatially. The fisheries sector is heavily regulated aiming at reaching and maintaining ecosystem integrity. Stakeholders are involved in research and decision making and their compliance with regulations is high.

\subsection{Pressures}

The socioeconomic scenario narratives were translated as projections of nutrient emission separately for point sources, non-point sources and for atmospheric deposition of nitrogen and phosphorus. Trajectories of non-point source loads were developed by accounting for changes in the nutrient inputs to the soil (manure, fertilizers and atmospheric deposition) driven by land use and socio-economic developments, and inter-annual variations and trends in precipitation.

The hydrological model applied to simulate impacts of precipitation on nutrient loading, EHYPE, is a process-based multi-basin model applied for Europe (Donnelly et al. 2013, 2017; Hundecha et al. 2016). The approach has been previously applied for regional climate simulations of the Baltic Sea, e.g. Meier et al. (2012). Here, improved versions of the regional and general circulation models and results of scenario simulations from the latest IPCC assessment report have been used (IPCC 2013).

The initial nutrient loadings were averages from flow-normalized loads during the period of 2010-12 (HELCOM 2015). The initial division of loads by sources and sectors was based on the latest source apportionment by HELCOM (2011). The regional SSPs were formalized into fisheries management objectives that were used as targets in the Policy Optimization Routine of the ecological model. 
For the 'Fossil-fuelled development'-scenario, the aggregated phosphorus ( $P$ ) loads will increase by $37-49 \%$ and nitrogen $(N)$ loads by $27-38 \%$ from the current level by the end of the century. Fisheries are driven by maximization of their contribution to the national economy. Within the 'Sustainable well-being'-scenario, the loads will gradually decrease from the initial level of 2010-12 to the target levels of $\mathrm{N}$ and $\mathrm{P}$ as specified in the Baltic Sea Action Plan (HELCOM 2007) by 2021, and remain at that level thereafter. The fisheries management objective is ecosystem integrity (defined as high total biomass, especially of the species with large body sizes such as seals). More details about the nutrient emission trajectories and the formulation of the fisheries management goals can be found in Saraiva et al. (2019), their Fig. 5 and Bauer et al. (2019), respectively.

\subsection{Aquatic ecosystem}

\section{Biogeochemical model}

The nutrient loads, river runoff from the catchment and the regionally downscaled climate forcing are used as inputs to the three-dimensional, coupled physical-biogeochemical model RCO-SCOBI that has been developed to study the biogeochemical nutrient cycling in the Baltic Sea (Almroth-Rosell et al. 2011; Eilola et al. 2009; Meier et al. 2003). This model handles physical, biogeochemical and ecological processes in the sea as well as sediment nutrient dynamics. The circulation model RCO has open boundaries in the northern Kattegat, where in case of inflow, temperature, salinity and nutrient values are nudged towards observed climatological profiles. Horizontal and vertical resolutions amount to $3.7 \mathrm{~km}$ and $3 \mathrm{~m}$, respectively. The biogeochemical model SCOBI simulates the dynamics of nitrate, ammonium, phosphate, oxygen and hydrogen sulphide concentrations (the latter as negative oxygen), three phytoplankton groups (diatoms, flagellates and others, cyanobacteria), zooplankton and detritus in the water column (Eilola et al., 2009). For further details of the RCO-SCOBI model, see Almroth-Rosell et al. (2011), Eilola et al. $(2009,2011)$ and Meier et al. (2003).

\section{Ecological model}

Selected outputs from the biogeochemical model (e.g. water temperature, salinity, oxygen conditions, phytoplankton biomass) were used as inputs to a spatial version of the Ecopath with Ecosim (Pauly et al. 2000; Walters et al. 1999) food-web model parametrised for the offshore central Baltic Sea ecosystem. The model comprises 22 functional groups, including 
phytoplankton, detritus, and various benthic and pelagic invertebrate and vertebrate consumers. The spatial version of the food-web model (Bauer et al. 2018) describes food-web interactions under the influence of changing temperature, oxygen and salinity conditions. Further, it considers the impacts of fisheries on commercially fished species in the central Baltic Sea. Fishing efforts under the two scenarios described here were defined using the 'Optimal Policy Search' routine in EwE (Christensen and Walters 2004). This routine estimates optimal fishing efforts assuming environmental conditions and socio-economic objectives of the fisheries according to the two scenarios (profit maximization under 'Fossil-fuelled development' and ecosystem integrity under 'Sustainable well-being'). More details about the setup of the scenario simulations and their outcomes in terms of changes in natural habitat quality and biodiversity are found in Bauer et al. (2019).

\section{PROJECTIONS OF SELECTED INDICATORS OF ECOSYSTEM SERVICES}

Next, we describe simulated development of the three selected indicators of ecosystem services: i) primary production as a key supporting ecosystem service, ii) commercial fish catches as an indicator of provisioning services and iii) number of summer days with cyanobacterial blooms as an indicator of recreational opportunities.

The main interactions in the modelled aquatic system related to these ecosystem service indicators and their relationships with global and regional drivers are shown in Figure 2. The production of phytoplankton depends primarily on the amount of nutrients available and temperature of the water. Phytoplankton production is the basis for the food web and therefore supports all provisioning services directly (via consumption by zooplankton) or indirectly (via sedimentation). Increased primary production leads to increased zooplankton production. Zooplankton is the main food source of pelagic fish such as sprat (Sprattus sprattus) and herring (Clupea harengus). These two species serve as food for cod (Gadus morhua). Increased production also increases sedimentation of organic matter, which in moderate amounts increases the biomass of benthic animals (e.g. Ehrnsten et al. 2019), but in excessive amounts can cause hypoxia at the seafloor, killing the benthic fauna and releasing phosphorus back to circulation (Conley et al. 2009; Vahtera et al. 2007). Hypoxia also reduces 
the food availability and suitable living space for demersal fish, such as cod and flounder (Platichtys flesus). The size of pelagic and demersal fish populations and fishing effort determine commercial catches.

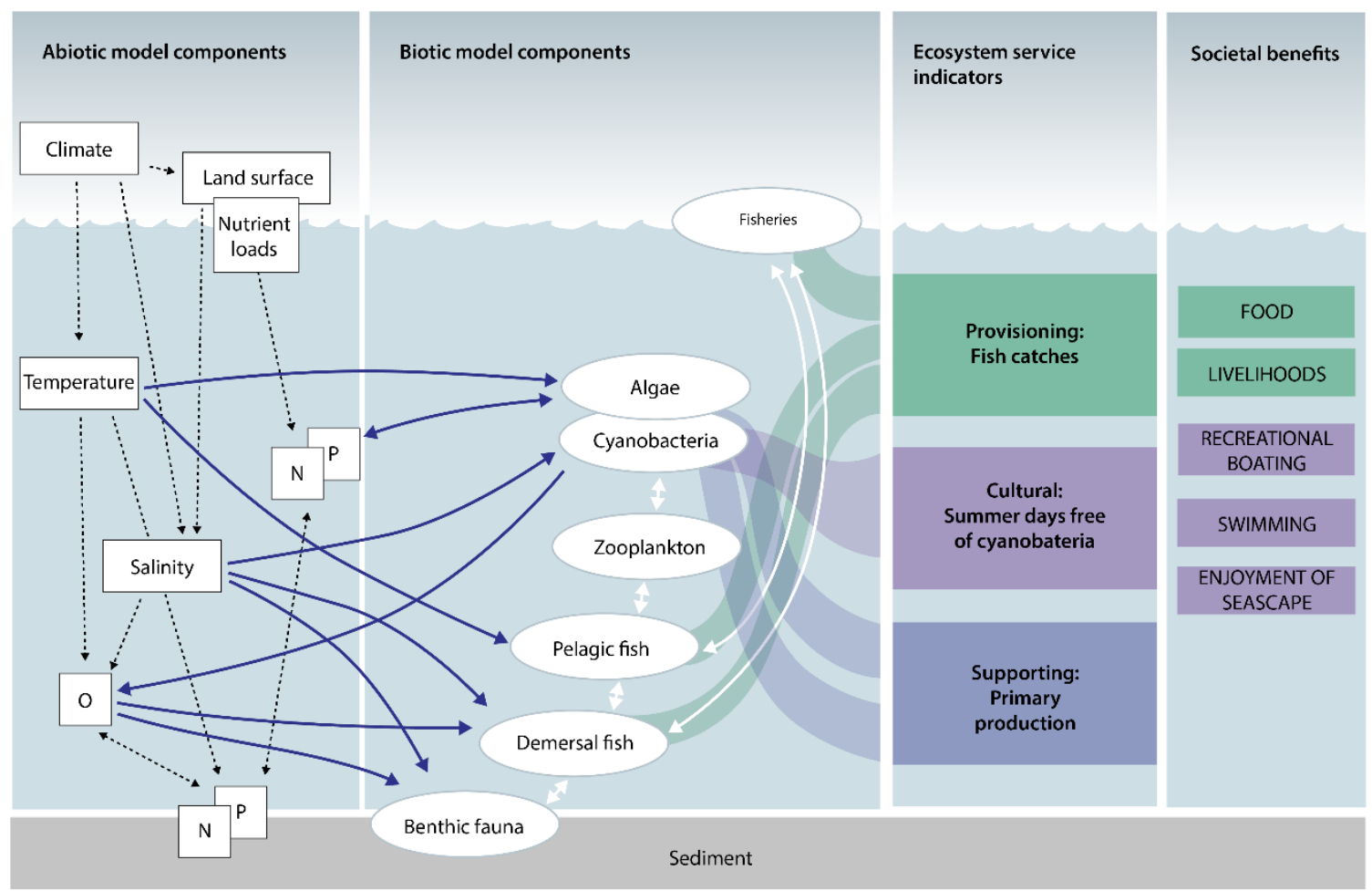

Figure 2. An aggregated view of the main interactions in the modelled aquatic ecosystem resulting in the selected supporting, provisioning and cultural ecosystem service indicators. Black dashed arrows indicate energy, momentum and matter flows, blue arrows indicate environment-food-web interactions and white arrows indicate food-web interactions. Some of the benefits associated with the indicators are shown to the right. To realise these benefits inputs from society are also needed (e.g. fish processing industry making the catch available as food, infrastructure providing access to beaches)

Phytoplankton production and community composition, more specifically the amount of cyanobacteria, are also linked to recreational opportunities. Spring phytoplankton are generally dominated by eukaryotic algae, but when the available dissolved nitrogen in the water is reduced, nitrogen-fixing cyanobacteria can form large blooms as long as there is dissolved phosphorus available. Excessive and frequent cyanobacteria blooms reduce the recreation possibilities directly by making the water unsuitable for swimming. Cyanobacteria 
blooms also indirectly reduce the enjoyment of other cultural ecosystem services (such as inspiration and aesthetic values) by impairing the state of the aquatic ecosystem.

\section{Primary production as an example of supporting ecosystem service}

Figure 3 shows the mean primary production in the Baltic Sea for the period (1986-2015) and two studied extreme scenarios towards the end of the current century (2069-2098). These maps correspond to the ensemble mean of the annual primary production (from the results of four GCMs) in each grid cell $(3.7 \times 3.7 \mathrm{~km})$ spatially integrated into the 13 basins.

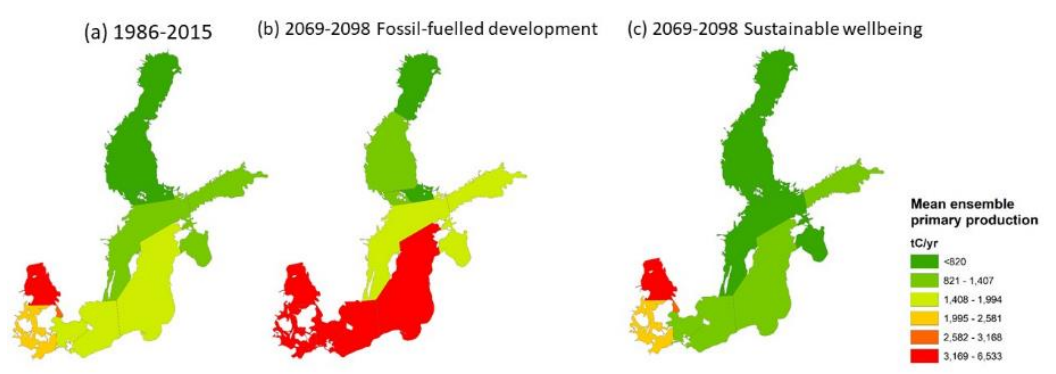

Figure 3. Ensemble mean primary production in the near past (a) and by the end of the century for two extreme scenarios: fossil-fueled development (b) and sustainable wellbeing (c), described in terms of tons $C$ year $^{-1}$

In the 'Sustainable well-being'-scenario, primary production at the end of the century will be considerably lower than under current conditions. Across basins, primary production will decrease by $20 \%$ on average, ranging from an increase of $10 \%$ in the Danish sounds to a reduction of $51 \%$ in the Gulf of Riga. As a consequence, oxygen consumption due to remineralization will be lower and oxygen conditions of the deep water will be improved. Further, water clarity will be upgraded because the water column will contain less particulate and dissolved organic material.

In the scenario of 'Fossil-fuelled development', primary production will be higher at the end of the century than currently. Primary production will increase by $96 \%$ across basins ranging from an increase of $44 \%$ in the Gulf of Finland to $172 \%$ in the Bornholm Basin. Primary production will increase the most in the coastal zone of the eastern Baltic Sea, where the 
rivers with large nutrient loads flow into the sea (not shown). As a further consequence of the high phosphorus loads, nitrogen fixation by cyanobacteria will increase. Cyanobacteria can fix gaseous dinitrogen $\left(\mathrm{N}_{2}\right)$ when there is a deficit of nitrogen in the water column, e.g. after the spring bloom, making nitrogen available for other phytoplankton species. Hence, the process of nitrogen fixation reinforces eutrophication.

\section{Fish catches as an example of provisioning ecosystem services}

Total catches predicted by the Ecopath with Ecosim model in both explored scenarios are higher than current catches. This, apart from changes in fish biomass, is caused by setting the fishing efforts in the two scenario simulations to higher values than in the 'current' model runs, based on the results of the 'Optimal Policy Search' procedure. Increase in total catches is fastest for the 'Fossil-fuelled development'-scenario (Figure 4), where increased primary production provides a basis for increased fish production (see Figure 3). Under the 'Sustainable well-being'-scenario primary production will decrease in the central Baltic Sea, but the ecosystem is still able to support relatively high catches. Improving oxygen conditions at the seafloor together with controlled fishing improve feeding conditions of demersal fish (Fig. 2).

$\begin{array}{ll}\text { (a) Current (2006-2015) } & \text { (b) Fossil-fuelled development (2069-2098) }\end{array}$

(c) Sustainable wellbeing (2069-2098)

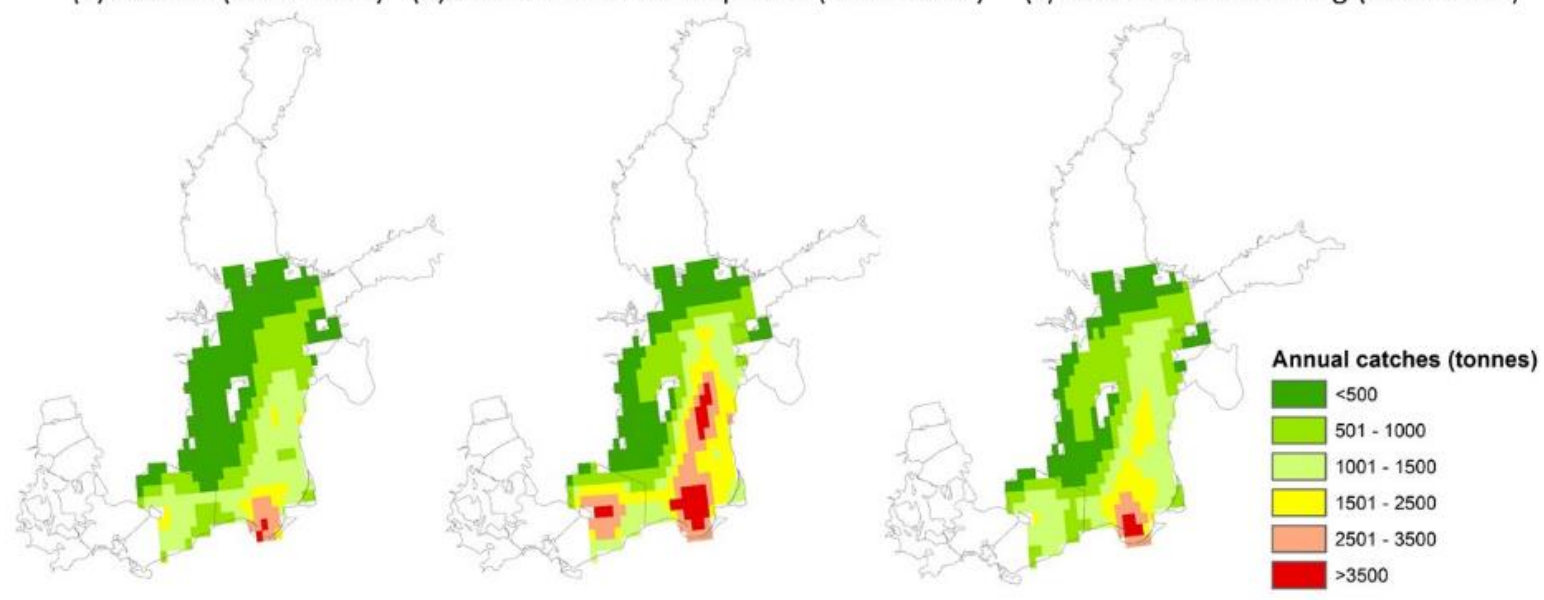

Figure 4. Spatial distribution of annual fish catches (tons) in the central Baltic Sea currently (a) and by the end of the century predicted by the Ecopath and Ecosim model under two extreme future scenarios, 'Fossil-fuelled development' (b) and 'Sustainable well-being' (c). 
The potential societal benefit based on catches does not only depend on their total amounts, but also on the species caught and their relative values. Model simulations show deviating trajectories for the species composition of catch and stock under the explored scenarios (Figure 5a). In the 'Fossil-fuelled development'-scenario, demersal fish will suffer from deteriorated seafloor conditions, while pelagic fish living higher in the water column benefit from increased primary and zooplankton production. Future catches under this scenario will consist mostly of pelagic fish. In the Baltic Sea, pelagic fish are smaller and on average of less commercial value than demersal fish and are mostly caught for industrial purposes. We see opposite patterns under the 'Sustainable well-being' scenario, where environmental conditions are suitable for reproduction and growth of demersal species. These species are caught for human consumption and are generally highly valuable in terms of catch value. Despite different species composition and total catches, the aggregate catch values in the two explored scenarios are about the same (Figure 5 b).
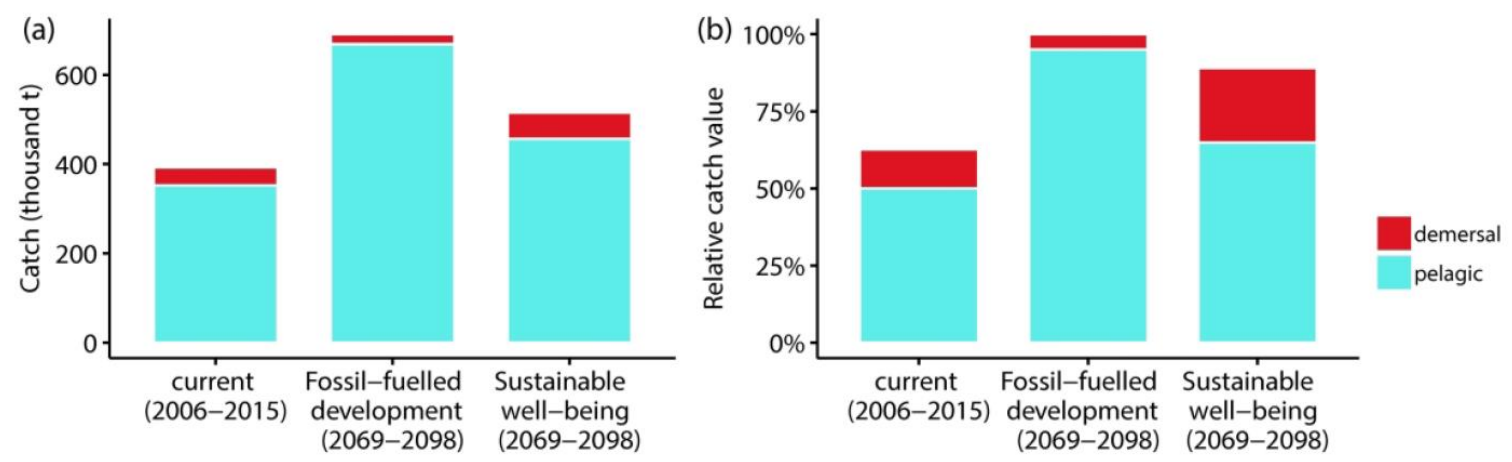

Figure 5. Catches (a) and relative catch value (b) of demersal (red) and pelagic (blue) fish in the Central Baltic predicted by the Ecopath and Ecosim model. Relative catch value is computed assuming the price per tonne is 1 for cod, 0.35 for flounder and 0.25 for sprat (relative market prices of these species in 2015). Cod and flounder are 'demersal' species and herring and sprat 'pelagic' species.

\section{Days of cyanobacterial blooms as an indicator of the availability of cultural ecosystem services}

Days of cyanobacterial blooms over a 30-year historical period and projections for the end of the century for the explored scenarios are shown in Figure 6. Results are described for five 
sub-basins where cyanobacteria blooms are most common. In the 'Fossil-fuelled development'- scenario, the mean number of cyanobacteria blooming days increase 16 - 25 $\%$ in the selected sub-basins by the end of the century. In the 'Sustainable well-being'scenario, the mean number of cyanobacteria blooming days decrease by 48 - $79 \%$ across five sub-basins. Especially the Eastern Gotland Basin would experience a drastic reduction in cyanobacteria blooms from on average 65 days to 14 days towards the end of the century. The projected ensemble annual means were significantly different from the historical period in both scenarios for all five sub-basins.

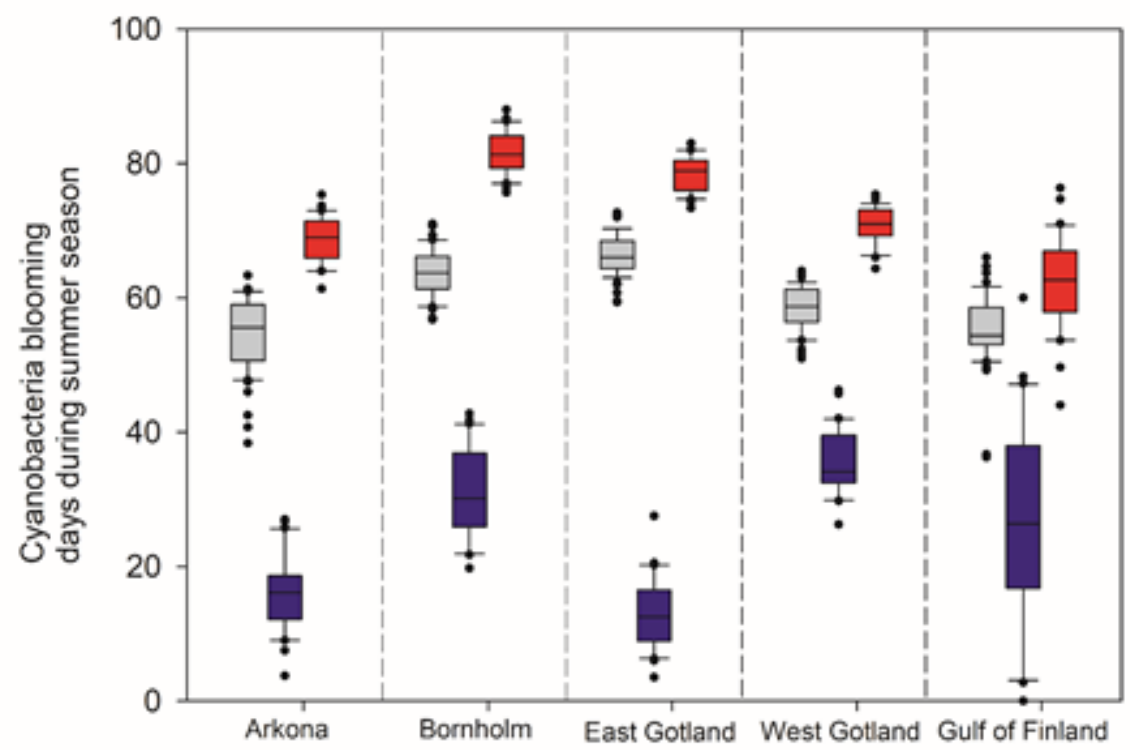

Figure 6. Tukey box plots describing the number of cyanobacteria blooming days per summer season, May to October for the recent past (1986-2015) denoted by grey box plots and for the end of the century (2069-2098) denoted by blue and red box plots for 'Sustainable well-being' and 'Fossil-fuelled development'-scenarios, respectively. The threshold concentration of cyanobacteria for the day to be considered a blooming day is $4 \mathrm{mg} \mathrm{Chl} / \mathrm{l}$. Annual numbers of blooming days are ensemble means of the results from four and three regionalized GCM runs for the end of the century under the 'Sustainable well-being' and 'Fossil-fuelled development' scenarios, respectively. For the recent past we used seven regionalized GCM runs. 


\section{DISCUSSION}

We developed an integrated modelling framework for studying the future provision of aquatic ecosystem services at relevant spatial and temporal scales. One novelty in comparison to earlier frameworks (e.g. Keeler et al. 2012) is the inclusion of regionally downscaled climate scenarios and socioeconomic futures as drivers of polluting and extractive uses of aquatic environments. Accounting for the plausible changes in the fundamental drivers of change is important for long-term projections and analyses. Long time horizon is relevant when studying marine environments where complex feedbacks and slow responses to disturbances are common (Österblom et al. 2013). The approach was showcased for a limited number of global futures and exemplary ecosystem services. However, the integrated framework is readily available for multiple model runs that would allow richer spread of plausible futures and fuller array of ecosystem services. The numerical modelling framework developed for the Baltic Sea is flexible for replacement of the modelling elements as relevant for the question studied and could be adapted to other coastal seas.

Our analysis of the two global future scenarios resulted in clearly deviating trajectories in the provision of marine ecosystem services. The 'Sustainable well-being'- scenario would support sustained and increasing flow of several marine ecosystem services. Under the 'Fossil-fuelled development'-scenario the catches of currently most highly valued fish species would decline and the opportunities for sea-based recreation would become scarcer. On the other hand, even under such high-end scenario the future possibilities for the enjoyment of many ecosystem services are not ruined. One explanation for this result is that the Baltic Sea ecosystem is still recovering from the peak nutrient loads in the 1980s. On the other hand, it is also possible that our ecological model does not adequately address all negative consequences of increased nutrient loads. For example, it does not consider potential changes in phytoplankton community composition (Suikkanen et al. 2013), which may affect aquatic consumers (Karjalainen et al. 2008). Finally, even though projected total catch values are rather similar in both scenarios, their socio-economic implications for the fishery sector would arguably be very different. Under the 'Fossil-fuelled development'-scenario diversity of work opportunities in the fishery would probably decline as the catch consists mostly of one type of fish. 
The impact of the pure climate affect was not studied here but it can be deduced from the comparison between scenario simulations under RCP4.5 and RCP8.5 assuming identical nutrient load scenarios (either SSP5 or SSP1). The climate impacts on biogeochemical cycles (nutrient and oxygen concentrations, primary production, nitrogen fixation, hypoxic area) were studied, inter alia, by Saraiva et al. (2019). Saraiva et al. (2019) concluded that the impacts of the changing climate within the range of the considered greenhouse gas concentration scenarios (RCP 4.5 and RCP 8.5) on biogeochemical cycles will be smaller than the impacts of the considered nutrient load changes corresponding to three global futures studied: SSP1, SSP2 or SSP5. Uncertainties of the projections due to biases in regional and global climate models, unknown emission and nutrient scenarios and natural variability are discussed in Saraiva et al. (2019) and Meier et al. (2018, 2019).

In general, the models used in this study do not explicitly represent the full range of biological diversity found in the Baltic Sea neither at the lower nor higher trophic levels. In principle it would be possible to increase the number of groups included in the Ecopath with Ecosim model. However, this would come at the cost of considerably increased model complexity. On the other hand, our model could provide information on ecosystem context for specialized models that are suited to represent the dynamics of top predators, like marine mammals and birds that are especially important from an ecosystem services perspective (Hammerschlag et al. 2019). Our general knowledge on which components of biodiversity contribute to which ecosystem services is rapidly increasing (Lavorel et al. 2017). This kind of improved biophysical understanding will help to design model structures that are most fit for the goal of estimating future provision of aquatic ecosystem services.

Long-term projections of ecosystem functions and services, prepared as responses to megatrends or plausible socioeconomic scenarios, serve multiple purposes. Firstly, simulations conducted over a wide range of plausible future conditions for what comes to the yet unknown development in population growth, technological development, life styles and other important drivers, increases our understanding about the range of plausible future states and functions of ecosystems, and system resilience to disturbances. Improved knowledge about different sources of uncertainty allow policy makers to reach more robust 
decisions over a wide range of possible futures (Moss et al. 2010). Secondly, long-term scenario projections can be applied as baselines or business-as-usual scenarios to assess the policy effort needed to reverse undesired trends under distinct, clearly defined global futures. Comparing the state of ecosystem services in the future projections to contemporary policy targets are also needed to develop cost-effective programmes of measures to close the future policy target gap. Thirdly, long-term projections of ecosystem services may inform us about the future winners and losers, whose needs require attention when designing environmental policies. For example, our analysis indicated the demersal fishery sector as the most vulnerable sector under the 'Fossil-fuelled development'-scenario. It also suggested that the decline in recreational bathing opportunities, and therefore, potential income from tourism under the same scenario would be largest around the coast of the Bornholm and East Gotland basins.

Long-run projections of integrated models may serve the implementation of regional sea conventions and international environmental agreements by providing information about how alternative policies and programmes of measures change pressures on the ecosystem on the long-term. For example, the EU Marine Strategy Framework Directive advocates a holistic management of anthropogenic pressures approach and requires periodic assessment of the programme of measures. In the Baltic Sea region, HELCOM periodically revises the environmental goals based on the best available information regarding the current state and pressures. Increased research information about the plausible pathways leading from anthropogenic drivers to ecosystems services would facilitate both policy processes by allowing the member states to get better prepared for the plausible undesired developments in the underlying drivers of marine pollution and extraction and adjust the policy and mitigation effort accordingly. The scenarios studied in this paper represent interpretations of how two alternative global futures may unfold at the regional level. However, in order to better understand the range of future outcomes, the simulations should be repeated to several plausible combinations of societal development and policy effort. 


\section{ACKNOWLEDGEMENTS}

This work resulted from the BONUS BALTICAPP project and was supported by BONUS (Art 185), funded jointly by the EU and the Academy of Finland, Innovation Fund Denmark, and Swedish Research Council for Sustainable Development. The work by BB, KBJ and BG is cofunded through the Baltic Nest Institute, which is supported by the Swedish Agency for Marine and Water Management through their grant 1: 11-Measures for marine and water environment. The research presented in this study is part of the Baltic Earth (Earth System Science for the Baltic Sea Region) program.

\section{REFERENCES}

Almroth-Rosell, E., Eilola, K., Hordoir, R., Meier, H.E.M. \& Hall, P.O.J. (2011) Transport of fresh and resuspended particulate organic material in the Baltic Sea - a model study. Journal of Marine Systems 87: 1-12.

Atkins, J.P., Burdon, D., Elliot, M., \& Gregory, A.J. (2011) Management of the marine environment: Integrating ecosystem services and societal benefits with the DPSIR framework in a systems approach. Marine Pollution Bulletin 62: 215-226.

Bateman, I. J., Harwood, A. R., Abson, D. J., Andrews, B., Crowe, A., Dugdale, S., ..., Termansen, M. (2013) Economic analysis for the UK national ecosystem assessment: synthesis and scenario valuation of changes in ecosystem services. Environmental and Resource Economics 57, 273-297.

Bauer, B., Meier, H.E.M., Casini, M., Hoff, A., Margoński, P., Orio, A.,... Tomczak, M.T. (2018) Reducing eutrophication increases spatial extent of communities supporting commercial fisheries: a model case study. ICES Journal of Marine Science, fsy023,

Bauer, B., Gustafsson, B.G., Hyytiäinen, K., Meier, H. E. M., Müller-Karulis, B., Saraiva, S., \& Tomczak M.T. (2019) Food web and fisheries in the future Baltic Sea. Ambio doi:10.1007/s13280-019-01229-3

Börger, T., Beaumont, N.J., Pendleton, L., Boyle, K.J., Cooper, P., Fletcher, S..., Austen, M.C. (2014) Incorporating ecosystem services in marine planning: The role of valuation. Marine Policy 2014: 161-170

Christensen, V. \& Walters, C. J. (2004) Trade-offs in ecosystem-scale optimization of fisheries management policies. Bulletin of Marine Science 74: 549-562.

Cole, S. \& Moksnes, P.-O. (2016) Valuing Multiple Eelgrass Ecosystem Services in Sweden: Fish Production and Uptake of Carbon and Nitrogen. Frontiers in Marine Science 13. 
Conley, D. J., Björck, S., Bonsdorff, E. Carstensen, J. , Destouni, G., Gustafsson, B.G.,..., Zillén, L. (2009) Hypoxia-related processes in the Baltic Sea. Environmental Science and Technology 43: 3412-3420.

Dieterich, C., Schimanke, S., Wang, S. , Väli, G., Liu, Y., Hordoir, R., Axell, L., Höglund, A. \& Meier, H.E.M. (2013) Evaluation of the SMHI coupled atmosphere-ice-ocean model RCA4-NEMO. Report Oceanography (RO), vol. 47, SMHI, Norrköping, Sweden, 1 edn.

Dieterich, C., Wang, S., Schimanke, S., Gröger, M., Klein, B., Hordoir, R., ..., H. E. M. Meier. 2019. Surface heat budget over the North Sea in climate change simulations. Atmosphere, 10, 272; doi:10.3390/atmos10050272

Donnelly, C., Arheimer, B., Capell, R. Dahne, J. \& Strömqvist, J. (2013) Regional overview of nutrient load in Europe - challenges when using a large-scale model approach, E-HYPE. Understanding fresh-water quality problems in a changing world., Proceedings of IAHS-IAPSO IASPEI Assembly, Gothenburg, Sweden, 1 edn.

Donnelly, C., Greuell, W., Andersson, J., Gerten, D., Pisacane, G., Roudier, P. \& Ludwig, F. (2017) Impacts of climate change on European hydrology at 1.5, 2 and 3 degrees mean global warming above preindustrial level. Climatic Change 143: 13-26.

Ehrnsten E., Norkko, A., Timmerman, K., Gustafsson, B.G. (2019) Benthic-pelagic coupling in coastal seas - modelling macrofaunal biomass and carbon processing in response to organic matter supply. Journal of Marine Systems 196: 36-47.

Eilola, K., Meier, H.E.M. \& Almroth, E. (2009) On the dynamics of oxygen, phosphorus and cyanobacteria in the Baltic Sea; A model study. Journal of Marine Systems 75: $163-184$.

Elmgren, R. 1989. Man's Impact on the Ecosystem of the Baltic Sea: Energy Flows Today and at the Turn of the Century. Ambio 18: 326-332.

Fisher, B., Turner, R.K. \& Morling, P (2009) Defining and classifying ecosystem services for decision making. Ecological Economics 68: 643-653.

Gröger, M. Dieterich, C., Meier, H.E.M. \& Schimanke, S. (2015) Thermal air-sea coupling in hindcast simulations for the North Sea and Baltic Sea on the NW European shelf. Tellus A: Dynamic Meteorology and Oceanography 67, 26911.

Gröger, M., Arneborg, L., Dieterich, C., Höglund, A., and Meier, H. E. M. (2019) Hydrographic changes in the North Sea and Baltic Sea projected in an ensemble of climate scenarios downscaled with a coupled regional ocean-sea ice-atmosphere model. Climate Dynamics. doi:10.1007/s00382-019-04908-9

Hägg H.E., Humborg C., Mörth C.-M., Medina M.R. \& Wulff F. 2010. Scenario analysis of on protein consumption and climate change effects on riverine $\mathrm{N}$ export to the Baltic Sea. Environmental Science and Technology 44: 2379-2385.

Haines-Yong, R. \& Potschin, M. 2012. CICES Version 4: Response to Consultation. Centre for Environmental Management, University of Nottingham 
Halpern, B.S., Longo, C., Hardy, D., McLeod, K.L., Samhouri, J.F, Katona, S.K., Kleisner, K., ..., Zeller, D. (2012) An index to assess the health and benefits of the global ocean. Nature 488: 615-620.

Hammerschlag, N., Schmitz, A.J., Flecker, A.S., Lafferty, K.D., Sih, A., Atwood, T.B.,..., Cooke, S.J. (2019) Ecosystem Function and Services of Aquatic Predators in the Anthropocene. Trends in Ecology and Evolution 34: 369-383.

Hattam, C., Atkins, J.P., Beaumont, N. , Börger, T., Böhnke-Henrichs, A., Burdon, D,..., Austen M.C. (2015) Marine ecosystem services: linking indicators to their classification. Ecological Indicators 49: 61-75.

HELCOM, 2007. HELCOM Baltic Sea Action Plan (adopted by the HELCOM Ministerial meeting, Krakow, Poland 15th November 2007)

HELCOM, 2011. The Fifth Baltic Sea Pollution Load Compilation (PLC-5) Balt. Sea Environ. Proc. No. 128

HELCOM, 2015. Updated Fifth Baltic Sea pollution load compilation (PLC-5.5). Baltic Sea Environment Proceedings No. 145

Hundecha, Y., Arheimer B., Donnelly, C. \& Pechlivanidis, I. (2016) A regional parameter estimation scheme for a pan-European multi-basin model. Journal of Hydrology: Regional Studies 6: 90-111.

ICES, 2019. ICES Advice on fishing opportunities, catch, and effort Baltic Sea ecoregion. Published 29 May 2019.

IPCC, 2013. IPCC Fifth Assessment Report (AR5), www.ipcc.ch/report/ar5/

Karjalainen, M., Pääkkönen, J.P., Peltonen, H., Sipiä, V., Caltonen, T. \& Viitasalo, M. (2008) Nodularin concentrations in Baltic Sea zooplankton and fish during a cyanobacterial bloom. Marine Biology 155: 483-491. https://doi.org/10.1007/s00227-008-1046-4

Keeler, B.L., Polasky, S., Brauman, K.A., Johnson, K.A., Finlay, J.C., O’Neill, A., Kovacs, K., Dalzell, B. (2012) Linking water quality and well-being for improved assessment and valuation of ecosystem services. Proceedings of the National Academy of Sciences of the United States of America PNAS 109: 18619-18624.

La Notte, A., D’Amato, D., Mäkinen, H., Paracchini, M.L., Liquete, C., Egoh, B., Geneletti, D. \& Crossman, N.D. (2017) Ecosystem services classifications: A system ecology perspective of the cascade framework. Ecological Indicators 74: 392-402.

Lavorel, S., Bayer, A., Bondeau, A., Lautenbach, S., Ruiz-Frau, A., Schulp, N. \& Marba, N. (2017) Pathways to bridge the biophysical realism gap in ecosystem services mapping approaches. Ecological Indicators 74: 241-260.

Liquete, C., Piroddi, C. , Drakou, E.G, Gurney, L. , Katsanevakis, S. , Charef, A., Egoh, B. (2013) Current status and future prospects for the assessment of marine and coastal ecosystem services: a systematic review. PLoS ONE 8:e67737. doi: 10.1371/journal.pone.0067737 
Mace, G.M. \& Bateman, I. (2011) Conceptual frameworks and methodology. In: UK National Ecosystem Assessment: understanding nature's value to society (eds. Watson, R and S. Albon). London: UK National Ecosystem Assessment (NEA).

Meier, H.E.M., Andersson, H.C. , Arheimer, B., Donelly, C., Eilola, K., Gustafsson, B.G. , ...., Zorita, E. (2014) Ensemble modelling of the Baltic Sea ecosystem to provide scenarios for management. Ambio 43: 37-48.

Meier, H.E.M., Döscher, R. , Faxén, T. (2003) A multiprocessor coupled ice-ocean model for the Baltic Sea: Application to salt inflow. Journal of Geophysical Research: Oceans 108.

Meier, H. E. M., Edman, M., Eilola, K., Placke, M., Neumann, T., Andersson, H. et al. (2018). Assessment of eutrophication abatement scenarios for the Baltic Sea by multimodel ensemble simulations. Frontiers in Marine Science, 5:440. doi: 10.3389/fmars.2018.00440.

Meier, H. E. M., Edman, M., Eilola, K., Placke, M., Neumann, T., Andersson, H., Brunnabend, S.-E., Dieterich, C., Frauen, C., Friedland, R., Gröger, M., Gustafsson, B. G., Gustafsson, E., Isaev, A., Kniebusch, M., Kuznetsov, I., Müller-Karulis, B., Naumann, M., Omstedt, A., Ryabchenko, V., Saraiva, S., and Savchuk, O. P. (2019) Assessment of uncertainties in scenario simulations of biogeochemical cycles in the Baltic Sea. Frontiers in Marine Science 6:46, doi:

10.3389/fmars.2019.00046

Meier, H.E.M., Müller-Karulis, B., Andersson, H. C., Dieterich, C., Eilola, K., Gustafsson, B. G.,..., Schimanke, S. (2012) Impact of climate change on ecological quality indicators and biogeochemical fluxes in the Baltic Sea: a multi-model ensemble study. Ambio 41, pp. 558-573.

Millennium Ecosystem Assessment, 2005. Ecosystems and Human Well-being: Synthesis. Island Press, Washington, DC. https://www.millenniumassessment.org/documents/document.356.aspx.pdf

Moss R.H., Edmonds, J.A., Hibbard, K.A., Manning, M.R., Rose, S.K., van Vuuren, D.P.,..., Wilbanks, T.J. (2010) The next generation of scenarios for climate change research and assessment. Nature 463: 747-756.

Nelson, E., Mendoza, G., Regetz, J., Polasky, S., Tallis, H., Cameron, D.R.,..., Shaw, M.R (2009) Modeling multiple ecosystem services, biodiversity conservation, commodity production, and tradeoffs at landscape scales. Frontiers in Ecology and the Environment 7: 4-11.

Nordhaus, W.D. (1992) An Optimal Transition Path for Controlling Greenhouse Gases. Science 258: 1315-1319.

O’Neill, B.C., Kriegler, E., Riahi, K., Ebi, K.L., Hallegatte, S., Carter, T.R., Mathur, R. \& van Vuuren, D.P. (2014) A new scenario framework for climate change research: the concept of shared socioeconomic pathways. Climatic Change 122: 387400 . 
Ochoa, V., \& Urbina-Cardona, N. (2017) Tools for spatially modeling ecosystem services: Publication trends, conceptual reflections and future challenges. Ecosystem Services 26: 155-169.

Parry, M.L., Rosenzweig, C., Iglesias, A., Livermore, M. \& Fischer, G. (2004) Effects of climate change on global food production under SRES emissions and socio-economic scenarios. Global Environmental Change 14: 53-67.

Pauly, D., Christensen, V. \& Walters, C. (2000) Ecopath, Ecosim, and Ecospace as tools for evaluating ecosystem impact of fisheries. ICES Journal of Marine Science 57: 697-706.

Pouso, S., Borja, Á., Martín, J. \& Uyarra, M.C. (2019) The capacity of estuary restoration to enhance ecosystem services: System dynamics modelling to simulate recreational fishing benefits. Estuarine, Coastal and Shelf Science 2017: 226236.

Reusch, T.B.H., Dierking, J., Andersson, H.C., Bonsdorff, E., Carstensen, J., Casini, M.,..., Zandersen, M. (2018) The Baltic Sea as a time machine for the future coastal ocean. Science Advances 4, eaar8195.

Riahi, K., van Vuuren, D.P., Kriegler, E., Edmonds, J., O’Neill, B.C., Fujimori, S., Bauer, N., ... Tavoni, M. 2017. The Shared Socioeconomic Pathways and their energy, land use, and greenhouse gas emissions implications: An overview. Global Environmental Change 42: 153-168 doi:110.1016/j.gloenvcha.2016.05.009

Rocha, J., Yletyinen, J., Biggs, R. Blenckner, T., Peterson, G. (2014) Marine regime shifts: drivers and impacts on ecosystems services. Philosophical Transactions of the Royal Society B 370: 20130273.

Saraiva S., Meier, H. E. M., Andersson, H., Höglund, A., Dieterich, C., Gröger, M., Hordoir, R. \& Eilola, K. (2019) Uncertainties in projections of the Baltic Sea ecosystem driven by an ensemble of global climate models. Frontiers in Earth Science, 6:244 doi: $10.3389 /$ feart.2018.00244

Suikkanen, S., Pulina, S., Engström, J., Lehtiniemi, M., Lehtinen, S., Brutemark, A., \& Lin, S. (2013) Climate change and eutrophication induced shifts in northern summer plankton communities. PLoS One, 8: e66475.

Vahtera, E., Conley, D. J., Gustafsson, B. G., Kuosa, H., Pitkänen, H., Savchuk, O.P.,...,Wulff, F. (2007) Internal ecosystem feedbacks enhance nitrogen-fixing cyanobacteria blooms and complicate management in the Baltic Sea. Ambio 36: 186-194.

Walters, C., Pauly, D. \& Christensen, V. (1999) ECOSPACE: prediction of mesoscale spatial patterns in trophic relationships of exploited ecosystems, with particular reference to impacts of marine protected areas. Ecosystems 2: 539-554.

Wang, S., Dieterich, C., Döscher, R., Höglund, A., Hordoir, R., Meier, H. E. M., Samuelsson, P. \& Schimanke, S. (2015) Development and evaluation of a new regional coupled atmosphere-ocean model in the North Sea and Baltic Sea, Tellus A: Dynamic Meteorology and Oceanography 67, 24284 
Zandersen, M., Hyytiäinen, K., Meier, H.E.M, Tomczak, M.T., Bauer, B., Haapasaari, P., ..., Van Vuuren, D.P. 2019. Shared socio-economic pathways extended for the Baltic Sea: exploring long-term environmental problems. Regional Environmental Change https://doi.org/10.1007/s10113-018-1453-0

Österblom, H., Merrie, A., Metian, M., Boonstra, W. J,. Blenckner, T. Watson, J. R.,...,Folke, C. 2013. Modeling Social-Ecological Scenarios in Marine Systems. BioScience 63: 735-744. 